\title{
Sod Competition in Peach Production: II. Establishment Beneath Mature Trees
}

\author{
D.M. Glenn and W.V. Welker \\ U.S. Department of Agriculture-Agricultural Research Service, Appalachian Fruit Research Station, 45 \\ Wiltshire Road, Kearneysville, WV 25430
}

Additional index words. excessive vegetative growth, light penetration, nutrition, orchard floor management, Prunus persica, yield efficiency

\begin{abstract}
Planting sod beneath peach trees (Prunus persica) to control excessive vegetative growth was evaluated from 1987 to 1993 in three field studies. Peach trees were established and maintained in 2.5 -m-wide vegetation-free strips for 3 years, and then sod was planted beneath the trees and maintained for 5 to 7 years. Reducing the vegetation-free area beneath established peach trees to a 30- or 60-cm-wide herbicide strip with three grass species (Festuca arundinacae, Festuca rubra, Poa trivialis), reduced total pruning weight/tree in 5 of 16 study-years and weight of canopy suckers in 6 of 7 study-years, while increasing light penetration into the canopy. Fruit yield was reduced by planting sod beneath peach trees in 5 of 18 study-years; however, yield efficiency of total fruit and large fruit $(\mathrm{kg}$ yield/cm² trunk area) were not reduced in one study and in only 1 year in the other two studies. Planting sod beneath peach trees increased available soil water content in all years, and yield efficiency based on evapotranspiration ( $\mathrm{kg}$ yield/cm soil water use plus precipitation) was the same or greater for trees with sod compared to the $2.5-\mathrm{m}$-wide herbicide strip. Planting sod beneath peach trees has the potential to increase light penetration into the canopy and may be appropriate for high-density peach production systems where small, efficient trees are needed.
\end{abstract}

Controlling excessive vegetative growth in peach production is necessary in order to maintain high productivity (Chalmers et al. 1981; Guilivo et al. 1984) and prevent canopy shading that reduces fruit bud initiation. Dwarfing rootstocks are successfully used in apple production (Lockard and Schneider, 1981) to limit vegetative growth, however, dwarfing peach rootstocks are not commercially available, even though some can reduce tree size by $50 \%$ (Layne, 1987). Dwarfing may be a secondary consideration in choosing a rootstock relative to pest resistance and short-life considerations. Gradziel and Beres (1993) have developed a semidwarf clingstone peach with $30 \%$ to $50 \%$ reduction in internode length; however, other semi-dwarf cultivars for fresh market are yet to be developed. Plant growth regulators can control tree size (Miller, 1988), however, environmental concerns limit their development in the United States.

Cultural practices remain the short-term solution to controlling excessive vegetative growth in peach production. In arid and semiarid climates, limiting root growth to the volume of soil wetted through deficit irrigation limited tree vigor (Boland et al. 1994; Chalmers et al. 1981; Ran et al. 1992). In temperate regions root growth is not exclusively limited to the soil volume wetted by irrigation and so would not limit tree growth. Williamson and Coston (1990) and Myers (1992) controlled tree vigor in a subhumid region by lining the lower extent of the rootzone with a rootimpermeable fabric. Welker and Glenn $(1985,1989)$ and Glenn and Welker (1996) used sod competition to control tree size in young peach trees, and Huslig et al. (1993) used sod competition to limit vegetative growth before stage III of fruit development and then killed the sod to prevent reduced fruit size. The premise of

Received for publication 25 Aug. 1995. Accepted for publication 7 Mar. 1996. Research conducted at USDA-ARS, Kearneysville, WVa. Use of trade names does not imply endorsement of the products named, nor criticism of similar ones not named. The cost of publishing this paper was defrayed in part by the payment of page charges. Under postal regulations, this paper therefore must be hereby marked advertisement solely to indicate this fact.

${ }^{1}$ Soil scientist.

${ }^{2}$ Weed scientist. these cultural techniques is that there is an equilibrium between the size of the root system and the above ground portion of the tree (Richards and Rowe, 1977). Boland et al. (1994) confirmed this concept by demonstrating a 4-fold difference in size for peach trees planted in soil volumes ranging from 0.025 to $1.0 \mathrm{~m}^{3}$. Mandre et al. (1995) further demonstrated that fruit growth was not reduced when shoot growth was reduced by root confinement. Glenn and Welker (1989a, 1993) and Parker et al. (1993) have shown that sod limits peach root development and shoot growth supporting the idea that both biological and physical restriction of the root system will reduce vegetative growth. Glenn and Welker (1996) demonstrated that reducing the size of the vegetation-free area beneath peach trees during a 6-year period reduced vegetative growth and tree size, however, yield efficiency was unaffected.

The present study determined whether sod species and width of the sod strip beneath established trees would reduce yield, vegetative growth and yield efficiency.

\section{Materials and Methods}

'Harmony', 'Redhaven', and 'Summerglo' on 'Halford' seedling rootstock were planted in hand-dug holes in 1987, 1984, and 1983, respectively. The studies were within $300 \mathrm{~m}$ of each other and were similarly managed following planting. All trees were cut back to a height of $1 \mathrm{~m}$ at planting. A randomized complete-block design with five replicates was used with blocks arranged perpendicular to the slope. Each plot was $3 \mathrm{~m}$ wide and contained three trees, with a guard tree between plots in the row. Tree rows were spaced $6 \mathrm{~m}$ with $4.5 \mathrm{~m}$ between trees within the row and were oriented parallel to the slope. The trees were pruned each spring in an open-center form. The 3-m-wide drive middle was maintained in a 'Kentucky-31' (K-31) tall fescue (Festuca arundinacea Schreb.) sod. Following planting, the 3-m tree row strip was kept vegetation-free using a residual herbicide treatment of $1.12 \mathrm{~kg}$ a.i./ha $N^{\prime}(3,4$-dichlorophenyl)- $N, N$-dimethylurea (diuron) plus $1.12 \mathrm{~kg}$ a.i./ha 5-chloro-3(1,1-dimethylethyl)-6-methyl-2,4(1H,3H) pyrimidinedione (terbacil). This residual herbicide treatment was used in growing seasons one and two for all studies. During the 
third and subsequent growing seasons, the tree row strip was kept vegetation-free using $0.45 \mathrm{~kg}$ a.i./ha 1,1 '-dimethyl-4,4'-bipyridinium (gramoxone).

In the late summer of the third growing season, the sod treatments were applied. In the 'Harmony' study, 'Reliant' red fescue (Festuca rubra) was planted $(224 \mathrm{~kg} / \mathrm{ha})$ in the tree row strip leaving either a 30 - or a 60 -cm-wide vegetation-free strip in the center of the tree row. The untreated control remained a $2.5-\mathrm{m}-$ wide vegetation-free strip. In the 'Redhaven' study, 'Reliant' red fescue (224 kg/ha) or rough meadow grass (Poa trivialis) $(112 \mathrm{~kg}$ / ha) was planted in the tree row strip leaving a 30 -cm-wide vegetation-free strip in the center of the tree row. The untreated control remained a 2.5 -m-wide vegetation-free strip. In the 'Summerglo' study, 'K-31' tall fescue was planted $(168 \mathrm{~kg} / \mathrm{ha})$ in the tree row strip leaving a $2.5-\mathrm{m}, 30-\mathrm{cm}$ - or $60-\mathrm{cm}$-wide vegetation-free strip in the center of the tree row.

In all three studies, trees were fertilized with $300 \mathrm{~kg} / \mathrm{ha}$ of $10 \mathrm{~N}-$ $8.3 \mathrm{P}-4.4 \mathrm{~K}$ in the spring of each year. Trees were dormant pruned annually and the weight of prunings/tree was measured. In the latter years of the study, the number and weight of canopy sucker shoots was also measured. Canopy sucker shoots were the vertically-oriented shoots originating from older wood in the interior of the canopy. Leaf samples were collected in July to determine leaf nitrogen percentage. Trunk diameter $30 \mathrm{~cm}$ above the soil line was measured at the end of each growing season and converted to trunk cross-sectional area. Fruit yield was measured from three to five pickings of all the fruit on the tree. All fruit harvested were sorted by size into categories: $<65 \mathrm{~mm}$ in diameter and $>65 \mathrm{~mm}$ in diameter (large fruit). Yield efficiency was calculated as yield $(\mathrm{kg}) /$ trunk cross-sectional area $\left(\mathrm{cm}^{2}\right)$.

Acrylic tubes (57 mm in diameter, $1 \mathrm{~m}$ in length) were installed midway between the center trees in each plot of the 'Redhaven' and 'Summerglo' studies. Soil water content was determined using a calibrated neutron moisture probe (model 503; Campbell Pacific Nuclear, Pacheco, Calif.). Soil water content was measured weekly throughout the growing season for the 0-30, 30-60 and 60-90 cm depths. Water use efficiency was calculated as yield $(\mathrm{kg}) /(\mathrm{cm}$ water use from May through August plus precipitation for May through August) for years in which there was at least $80 \%$ of a full crop. Water use efficiency was based on the annual increase in trunk cross-sectional area $\left(\mathrm{cm}^{2}\right) /(\mathrm{cm}$ water use from May through August plus precipitation for May through August (cm).

The depth of the A horizon in the three study areas was measured in two soil cores from each plot. The samples were collected midway between the center trees in each plot in 1993.

Light penetration through the canopy was measured with a 1-mline quantum sensor (LI-COR, Lincoln, Neb.) in the 'Redhaven' and 'Summerglo' studies. The light bar was placed at ground level on permanent and level stakes positioned 1 and $2 \mathrm{~m}$ from the tree in line with the tree row and on both sides of the tree. The light bar was aligned parallel to the tree row. Before measuring each tree, a full sun reading was made, and the readings below the canopy were expressed as percentage of full sun. Readings were made on uniformly clear or uniformly overcast days. Light penetration data were collected on nine dates in 1992 and five dates in 1993.

Differences in canopy surface temperature from ambient air temperature were measured on nine dates in 1988 in the 'Redhaven' and 'Summerglo' studies with an infrared thermometer (model 110; Everest Scientific, Tustin, Calif.). The infrared thermometer was elevated to $3 \mathrm{~m}$ and aimed at a $30^{\circ}$ angle below the horizontal. This orientation measured the canopy minus air temperature of the canopy top interior. Ambient air temperature was sensed by a thermistor extended $20 \mathrm{~cm}$ from the infrared thermometer. Four readings were made around the tree and averaged. A single tree in each plot was measured at each sampling date. All treatments were measured in the 'Redhaven' study however, only the 2.5-m and 30-

Table 1. Effect of vegetation-free strip width on growth, yield, and leaf nitrogen for 'Harmony' peach.

\begin{tabular}{|c|c|c|c|c|c|c|c|c|c|c|c|c|c|}
\hline \multirow{2}{*}{$\begin{array}{l}\text { Width of } \\
\text { vegetation-free } \\
\text { strip } \\
\text { (m) }\end{array}$} & \multirow[b]{2}{*}{ Year } & \multicolumn{2}{|c|}{$\begin{array}{c}\text { Total yield } \\
(\mathrm{kg} / \text { tree })\end{array}$} & \multicolumn{2}{|c|}{$\begin{array}{c}\text { Yield of fruit }>65 \mathrm{~mm} \\
\text { in diam } \\
(\mathrm{kg} / \text { tree }) \\
\end{array}$} & \multirow{2}{*}{$\begin{array}{l}\text { Trunk } \\
\text { area } \\
\left(\mathrm{cm}^{2}\right)\end{array}$} & \multirow{2}{*}{$\begin{array}{l}\text { Yield } \\
\text { efficiency } \\
\left(\mathrm{kg} \cdot \mathrm{cm}^{-2}\right)\end{array}$} & \multirow{2}{*}{$\begin{array}{c}\text { Large } \\
\text { fruit } \\
\text { yield } \\
\text { efficiency } \\
\left(\mathrm{kg} \cdot \mathrm{cm}^{-2}\right)\end{array}$} & \multicolumn{2}{|c|}{$\begin{array}{l}\text { Pruning } \\
\text { total wt } \\
(\mathrm{kg} / \text { tree })\end{array}$} & \multicolumn{2}{|c|}{$\begin{array}{c}\text { Canopy sucker } \\
\text { pruning wt } \\
(\mathrm{kg} / \mathrm{tree})\end{array}$} & \multirow[b]{2}{*}{$\begin{array}{c}\text { Leaf } \mathrm{N} \\
(\%)\end{array}$} \\
\hline & & $\begin{array}{c}\text { Measured } \\
\text { mean }\end{array}$ & $\begin{array}{c}\text { Adjusted } \\
\text { mean }\end{array}$ & $\begin{array}{c}\text { Measured } \\
\text { mean }\end{array}$ & $\begin{array}{c}\text { Adjusted } \\
\text { mean }\end{array}$ & & & & $\begin{array}{c}\text { Measured } \\
\text { mean }\end{array}$ & $\begin{array}{c}\text { Adjusted } \\
\text { mean }\end{array}$ & $\begin{array}{c}\text { Measured } \\
\text { mean }\end{array}$ & $\begin{array}{c}\text { Adjusted } \\
\text { mean }\end{array}$ & \\
\hline 2.5 & 89 & 4.9 & $4.7^{\mathrm{z}}$ & 4.9 & 5.6 & 58 & 0.14 & 0.14 & & & & & $2.89 \mathrm{Az}$ \\
\hline 0.6 & 89 & 3.2 & 3.8 & 3.2 & 3.1 & 57 & 0.07 & 0.07 & & & & & $2.58 \mathrm{~B}$ \\
\hline 0.3 & 89 & 3.0 & 3.5 & 3.0 & 2.5 & 44 & 0.06 & 0.06 & ND & ND & ND & ND & $2.33 \mathrm{~B}$ \\
\hline 2.5 & 90 & 15.5 & 12.6 & & & 72 & 0.25 & & & & & & $2.79 \mathrm{~A}$ \\
\hline 0.6 & 90 & 11.0 & 10.2 & & & 69 & 0.17 & & & & & & $2.75 \mathrm{~A}$ \\
\hline 0.3 & 90 & 8.3 & 9.0 & $\mathrm{ND}^{\mathrm{y}}$ & ND & 54 & 0.15 & ND & ND & ND & ND & ND & $2.27 \mathrm{~B}$ \\
\hline 2.5 & 91 & 35.3 & 30.9 & 28.6 & 25.2 & & & & $7.5 \mathrm{~A}^{\mathrm{x}}$ & $6.2 \mathrm{~A}$ & & & 3.06 \\
\hline 0.6 & 91 & 23.6 & 24.9 & 16.0 & 17.0 & & & & $5.0 \mathrm{~B}$ & $5.4 \mathrm{~B}$ & & & 2.76 \\
\hline 0.3 & 91 & 19.6 & 22.6 & 14.8 & 17.1 & ND & ND & ND & $3.7 \mathrm{~B}$ & $4.5 \mathrm{~B}$ & ND & ND & 2.65 \\
\hline 2.5 & 92 & 38.7 & 34.9 & 36.6 & 33.2 & 88 & 0.38 & 0.36 & 3.2 & $2.6 \mathrm{~A}$ & $2.2 \mathrm{~A}$ & $1.7 \mathrm{~A}$ & $3.07 \mathrm{~A}$ \\
\hline 0.6 & 92 & 31.4 & 32.7 & 30.0 & 31.5 & 79 & 0.37 & 0.35 & $1.2 \mathrm{~B}$ & $1.4 \mathrm{~B}$ & $0.8 \mathrm{~B}$ & $1.0 \mathrm{~B}$ & $2.63 \mathrm{~B}$ \\
\hline 0.3 & 92 & 24.7 & 29.4 & 24.0 & 26.3 & 66 & 0.35 & 0.34 & $0.8 \mathrm{~B}$ & $1.1 \mathrm{~B}$ & $0.4 \mathrm{~B}$ & $0.7 \mathrm{~B}$ & $2.60 \mathrm{~B}$ \\
\hline 2.5 & 93 & 23.4 & 18.5 & 21.6 & 16.9 & 95 & 0.24 & 0.22 & $7.2 \mathrm{~A}$ & $6.7 \mathrm{~A}$ & $3.8 \mathrm{~A}$ & $3.4 \mathrm{~A}$ & 3.49 \\
\hline 0.6 & 93 & 17.2 & 18.7 & 16.4 & 17.9 & 87 & 0.19 & 0.18 & $4.0 \mathrm{~B}$ & $4.2 \mathrm{~B}$ & $1.7 \mathrm{~B}$ & $1.8 \mathrm{~B}$ & 3.63 \\
\hline 0.3 & 93 & 12.3 & 15.6 & 11.6 & 14.9 & 69 & 0.17 & 0.16 & $3.0 \mathrm{~B}$ & $3.3 \mathrm{~B}$ & $1.0 \mathrm{~B}$ & $1.2 \mathrm{~B}$ & 3.49 \\
\hline 2.5 & 94 & & & & & & & & $5.2 \mathrm{~A}$ & $4.4 \mathrm{~A}$ & $3.7 \mathrm{~A}$ & $2.9 \mathrm{~A}$ & \\
\hline 0.6 & 94 & & & & & & & & $3.5 \mathrm{AB}$ & $3.8 \mathrm{AB}$ & $2.1 \mathrm{~B}$ & $2.4 \mathrm{~B}$ & \\
\hline 0.3 & 94 & ND & ND & ND & ND & ND & ND & ND & $2.6 \mathrm{~B}$ & $3.1 \mathrm{~B}$ & $1.3 \mathrm{~B}$ & $1.8 \mathrm{~B}$ & ND \\
\hline
\end{tabular}

\footnotetext{
${ }^{\mathrm{z}}$ Adjusted mean from analysis of covariance, using depth of 'A' horizon as the covariate $P<0.05$

${ }^{\mathrm{x}}$ Mean separation within columns and years at $P<0.05$ by Ryan-Einot-Gabriel-Welsch test. Nonsignificant comparisons have no letter.

' No data.
} 
cm-wide vegetation-free strip were measured in the 'Summerglo' study. Measurements were made under clear sky conditions near solar noon.

Yield, tree growth, and leaf $\mathrm{N}$ percentage data were initially analyzed using a split plot in time design with treatment as the main plot and year as the subplot. When treatment $\times$ year interactions were significant, data were analyzed by year. Soil water content, canopy minus air temperature, and light penetration data were analyzed in a split plot design with sod treatment as the main plot and date of sampling as the subplot; the date $\times$ treatment interactions were not significant for light penetration and canopy minus air temperature. An LSD $(P=0.05)$ was calculated for each soil depth to separate soil water content means. Analysis of covariance using the depth of the ' $\mathrm{A}$ ' horizon as the covariate was applied to the growth and yield response. Only the 'Harmony' study had a significant covariance response and adjusted means were calculated for the growth and yield responses. Treatment means were separated using Ryan-Einot-Gabriel-Welsch mean separation technique at $P=0.05$.

\section{Results}

Harmony study. The 0.3- and 0.6-m-wide vegetation-free strip did not reduce total yield, large fruit yield, trunk cross-sectional area, or yield efficiency (Table 1) compared to the 2.5-m-wide vegetation-free control. These growth parameters were related to the depth of the ' $A$ ' horizon, however, analysis of covariance indicated no treatment effect on the means adjusted to the average depth of the 'A' horizon. The sod treatments reduced total pruning weights and the weight of canopy suckers in all years. These pruning parameters were related to the depth of the ' $A$ ' horizon and analysis of covariance indicated significant treatment effects on the adjusted means. Leaf nitrogen percentage was reduced by the 30 - and $60-\mathrm{cm}$-wide vegetation-free strip in 3 of the 5 years, and 2 of the 5 years, respectively. Trees in the $2.5-\mathrm{m}$ vegetation-free strip had the highest percentage of $\mathrm{N}$ in 3 of 5 years.

Redhaven study. The sod treatments of Poa trivialis and Festuca rubra reduced total and large fruit yield in the last 2 years of the 7 year study compared to the 2.5 -m control (Table 2). Yield and large fruit yield efficiency were reduced by the sod treatments in the last year of the study. The weight of canopy suckers was reduced by the sod treatments in the last 2 years of the study. Leaf $\mathrm{N}$ percentage was reduced by the sod treatments in 1 of 7 years. Planting sod of either species beneath peach trees did not reduce trunk cross-sectional area or total pruning weight in any year of the study compared to the $2.5-\mathrm{m}$-wide vegetation-free control. Light levels beneath the canopy $1 \mathrm{~m}$ from the trunk were unaffected by the sod treatments compared to the 2.5 -m control, however, $2 \mathrm{~m}$ from the trunk both sod treatments increased light penetration in 1992 and the Poa trivialis treatment increased light penetration in 1993. Water use efficiency was not affected by the sod treatments, except in 1991 in which trees in the Festuca runda treatment had a higher yield-based water use efficiency than those in the Poa trivialis treatment and the 2.5-m strip had the highest growth-

Table 2. Effect of grass species on growth, yield, leaf nitrogen and light penetration for 'Redhaven' peach

\begin{tabular}{|c|c|c|c|c|c|c|c|c|c|c|c|c|c|}
\hline \multirow[b]{4}{*}{ Treatment } & \multirow[b]{4}{*}{ Year } & \multirow{4}{*}{$\begin{array}{c}\text { Total } \\
\text { yield } \\
\text { (kg/tree) }\end{array}$} & \multirow{4}{*}{$\begin{array}{c}\text { Yield } \\
\text { efficiency } \\
\left(\mathrm{kg} \cdot \mathrm{cm}^{-2}\right)\end{array}$} & \multirow{4}{*}{$\begin{array}{c}\text { Yield } \\
\text { of } \\
\text { fruit } \\
>65 \mathrm{~mm} \\
\text { in diam } \\
\text { (kg/tree) }\end{array}$} & \multirow{4}{*}{$\begin{array}{c}\text { Large } \\
\text { fruit } \\
\text { yield } \\
\text { efficiency } \\
\left(\mathrm{kg} \cdot \mathrm{cm}^{-2}\right)\end{array}$} & \multirow{4}{*}{$\begin{array}{c}\text { Trunk } \\
\text { area } \\
\left(\mathrm{cm}^{2}\right)\end{array}$} & \multirow{4}{*}{$\begin{array}{c}\text { Total } \\
\text { pruning } \\
\text { wt } \\
\text { (kg/tree) }\end{array}$} & \multirow{4}{*}{$\begin{array}{c}\text { Canopy } \\
\text { sucker } \\
\text { pruning } \\
\text { wt } \\
\text { (kg/tree) }\end{array}$} & \multirow{4}{*}{$\begin{array}{c}\text { Leaf } \\
\mathrm{N} \\
(\%)\end{array}$} & \multirow{3}{*}{\multicolumn{2}{|c|}{$\begin{array}{c}\text { Full sunlight } \\
\text { penetration } \\
\text { into } \\
\text { canopy } \\
(\%) \\
\text { Distance } \\
\text { from } \\
\text { trunk }\end{array}$}} & \multicolumn{2}{|c|}{$\begin{array}{l}\text { Water-use } \\
\text { efficiency }\end{array}$} \\
\hline & & & & & & & & & & & & Yield- & $\begin{array}{c}\text { Growth- } \\
\text { based } \\
\left(\mathrm{cm}^{2}\right.\end{array}$ \\
\hline & & & & & & & & & & & & $\begin{array}{c}\text { based } \\
\text { (kg } \\
\text { fruit) }\end{array}$ & $\begin{array}{c}\text { annual } \\
\text { trunk } \\
\text { growth) }\end{array}$ \\
\hline & & & & & & & & & & $1 \mathrm{~m}$ & $2 \mathrm{~m}$ & Water & $\mathrm{se}(\mathrm{cm})$ \\
\hline Poa trivialis & 87 & & & & & 59.6 & & & 2.6 & & & & \\
\hline 2.5-m strip & 87 & & & & & 57.1 & & & 2.7 & & & & \\
\hline Festuca rubra & 87 & $\mathrm{ND}^{\mathrm{z}}$ & ND & ND & ND & 58.4 & ND & ND & 2.7 & ND & ND & ND & ND \\
\hline Poa trivialis & 88 & 61.0 & 0.96 & 38.6 & 0.60 & 64.4 & 2.0 & & 2.9 & & & 1.1 & 0.1 \\
\hline 2.5-m strip & 88 & 84.2 & 1.36 & 44.2 & 0.68 & 62.0 & 2.4 & & 3.2 & & & 1.5 & 0.1 \\
\hline Festuca rubra & 88 & 67.5 & 1.06 & 40.5 & 0.63 & 62.8 & 2.0 & ND & 2.9 & ND & ND & 1.2 & 0.1 \\
\hline Poa trivialis & 89 & 27.8 & 0.34 & 27.3 & 0.33 & 81.4 & 2.8 & & 2.9 & & & & 0.6 \\
\hline 2.5-m strip & 89 & 30.1 & 0.37 & 29.1 & 0.35 & 79.6 & 4.1 & & 2.9 & & & & 0.6 \\
\hline Festuca rubra & 89 & 28.4 & 0.34 & 27.7 & 0.34 & 80.1 & 2.5 & ND & 2.8 & ND & ND & ND & 0.6 \\
\hline Poa trivialis & 90 & 13.4 & 0.13 & 4.4 & 0.04 & 100.6 & 6.9 & & 2.5 & & & & 0.5 \\
\hline 2.5-m strip & 90 & 18.9 & 0.19 & 6.3 & 0.06 & 99.4 & 7.8 & & 2.6 & & & & 0.5 \\
\hline Festuca rubra & 90 & 15.6 & 0.17 & 6.8 & 0.07 & 100.8 & 7.3 & ND & 2.6 & ND & ND & ND & 0.5 \\
\hline Poa trivialis & 91 & 66.2 & 0.63 & 24.6 & 0.22 & 102.9 & 4.5 & & $3.0 \mathrm{~B}$ & & & $3.3 \mathrm{~B}$ & $0.1 \mathrm{~B}$ \\
\hline 2.5-m strip & 91 & 74.9 & 0.69 & 28.4 & 0.26 & 107.7 & 5.8 & & $3.3 \mathrm{~A}$ & & & 4.1 AB & $0.5 \mathrm{~A}$ \\
\hline Festuca rubra & 91 & 58.9 & 0.58 & 29.9 & 0.18 & 101.5 & 5.3 & ND & $3.0 \mathrm{~B}$ & ND & ND & $5.1 \mathrm{~A}$ & $0.1 \mathrm{~B}$ \\
\hline Poa trivialis & 92 & $19.9 \mathrm{~B}$ & 0.16 & $14.0 \mathrm{~B}$ & 0.15 & 118.8 & 5.3 & $2.4 \mathrm{~B}$ & 2.5 & 30 & $40 \mathrm{~A}$ & & 0.4 \\
\hline 2.5-m strip & 92 & $31.9 \mathrm{~A}$ & 0.27 & $28.4 \mathrm{~A}$ & 0.25 & 122.7 & 7.2 & $4.0 \mathrm{~A}$ & 2.8 & 32 & $33 \mathrm{~B}$ & & 0.4 \\
\hline Festuca rubra & 92 & $14.4 \mathrm{~B}$ & 0.13 & $19.4 \mathrm{~B}$ & 0.12 & 110.8 & 4.6 & $1.8 \mathrm{~B}$ & 2.7 & 32 & $40 \mathrm{~A}$ & ND & 0.4 \\
\hline Poa trivialis & 93 & $49.2 \mathrm{~B}$ & $0.39 \mathrm{~B}^{\mathrm{y}}$ & $30.1 \mathrm{~B}$ & $0.24 \mathrm{~B}$ & 125.8 & 3.0 & $0.8 \mathrm{~B}$ & 3.5 & 35 & $41 \mathrm{~A}$ & 1.7 & 0.2 \\
\hline 2.5-m strip & 93 & $69.2 \mathrm{~A}$ & $0.51 \mathrm{~A}$ & $41.9 \mathrm{~A}$ & $0.31 \mathrm{~A}$ & 136.9 & 4.5 & $2.0 \mathrm{~A}$ & 3.6 & 32 & $26 \mathrm{~B}$ & 1.4 & 0.4 \\
\hline Festuca rubra & 93 & $46.7 \mathrm{~B}$ & $0.37 \mathrm{~B}$ & $28.5 \mathrm{~B}$ & $0.23 \mathrm{~B}$ & 125.7 & 3.2 & $1.0 \mathrm{~B}$ & 3.7 & 32 & $31 \mathrm{~B}$ & 1.4 & 0.5 \\
\hline
\end{tabular}

${ }^{\mathrm{z} N o}$ data.

${ }^{y}$ Mean separation within columns and years at $P<0.05$ by Ryan-Einot-Gabriel-Welsch test. Nonsignificant comparisons have no letter. 

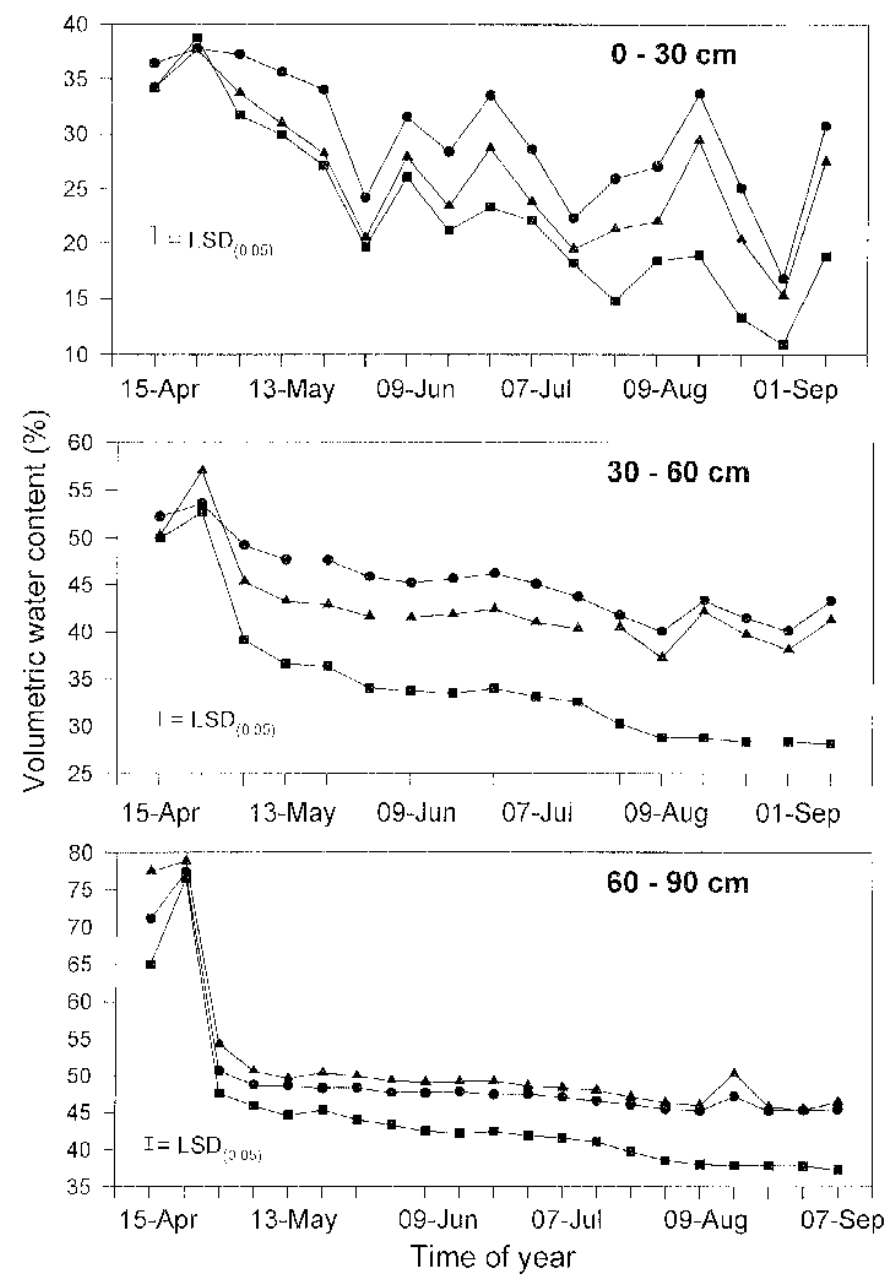

Fig. 1.Effect of vegetation-free strip width on soil water content of the 'Summerglo' study in $1993.02 .5 \mathrm{~m}, 0.6 \mathrm{~m}, \boldsymbol{\Delta} 0.3 \mathrm{~m}$.

based water use efficiency. Canopy minus air temperature was lowest in the $2.5-\mathrm{m}$-wide vegetation-free strip treatment $\left(-3.6^{\circ} \mathrm{C}\right)$, highest in the Festuca rubra treatment $\left(-3.1^{\circ} \mathrm{C}\right)$, and not different from the other treatments in the Poa trivialis treatment $\left(-3.3^{\circ} \mathrm{C}\right)$ across nine sampling dates in 1988. Soil water content was lowest in the 2.5-m-wide vegetation-free strip compared to the sod treatments for all depths and all years. Neither sod treatment consistently maintained the highest soil water content over the treatment period. Although data were collected from 1987 to 1993, data from 1993 is presented to represent other years (Fig. 1).

Summerglo study. Total yield was reduced by the sod treatments in the last 2 years of the 7 year study (Table 3 ). Total yield, yield of large fruit, and yield efficiency were reduced in 1989 due to frost damage of buds. Large fruit yield was reduced by the 30$\mathrm{cm}$-wide vegetation-free strip in 1992. Establishing a sod beneath mature peach trees did not reduce trunk cross-sectional area or yield efficiency in any year of the study compared to the $2.5-\mathrm{m}$ wide vegetation-free control. Total pruning weight and the weight of the canopy suckers were only reduced by the narrow vegetationfree strips in the last year of the study. Leaf nitrogen percentage was reduced by the sod treatments in 2 of the 7 years. Light levels beneath the canopy $1 \mathrm{~m}$ from the trunk were increased by the sod treatments in 1992 and unaffected at the 2-m distance. In 1993, light levels beneath the canopy $1 \mathrm{~m}$ from the trunk were unaffected by the sod treatments, however, the sod treatments increased light penetration $2 \mathrm{~m}$ from the trunk. Water use efficiency was not affected by the sod treatments except in 1992 where the 2.5-m-strip had the highest growth-based water use efficiency. Canopy minus air temperature was lower in the 2.5 -m-wide vegetation-free strip $\left(-3.6^{\circ} \mathrm{C}\right)$ compared to the $30 \mathrm{~cm}$ wide vegetation-free strip $(-3.1$ ${ }^{\circ} \mathrm{C}$ ) across 9 sampling dates in 1988. Soil water content was lowest in the 2.5-m-wide vegetation-free strip compared to the sod treatments for all depth and all years. Neither sod treatment consistently maintained the highest soil water content over the treatment period. Although data were collected from 1986 to 1993, data from 1993 is presented to represent other years (Fig. 2).

\section{Discussion}

Establishing a sod beneath established peach trees reduced yield in some but not all of the study areas. Yield reduction did not occur for 4 and 3 years following sod treatment application in the 'Redhaven' and 'Summerglo' studies, respectively (Tables 2 and 3 ). The 'Harmony' study did not have yield reductions that were significant at $P=0.05$, even though 1991 and 1993 had a $50 \%$ yield reduction due to the 30 -cm-wide vegetation-free strip treatment. The 'Harmony' study had high yield variation that was significantly correlated to the depth of the A horizon in the field plots. Analysis of covariance and adjusting the 'Harmony' yield means for depth of the A horizon resulted in a smaller range of yield levels but no significant difference in adjusted yield means. The 'Harmony' study had the deepest A horizon (mean of $22 \mathrm{~cm}$ ) and demonstrated no yield reduction due to the sod treatments. The 'Redhaven' study had the shallowest A horizon (mean of $17 \mathrm{~cm}$ ) and demonstrated a reduction in total and large fruit yield in 1992 and 1993. The 'Summerglo' study had an intermediate depth of the A horizon (mean of $19 \mathrm{~cm}$ ) and demonstrated a less dramatic though significant reduction in total yield in 1992 and 1993 with only 1992 indicating a significant reduction in large fruit yield. The depth of the A horizon was not a significant covariate in the 'Redhaven' and 'Summerglo' studies. It appears that the fertility of the soil, as reflected by the depth of the A horizon, may influence the impact of sod management. Trees growing on a deep fertile soil can maintain their yield potential and tolerate sod within the traditional tree row, whereas trees on shallower less fertile soils become stressed to the point where yield is reduced. This is a tentative conclusion, because different cultivars were studied at the different sites, yet practical experience would suggest that weed control is more important in maintaining yield and fruit size on shallow soils than on deep soils.

Yield efficiency was not significantly reduced at $P=0.05$ by the sod treatments in the 'Harmony' and 'Summerglo' studies and only in one year in the 'Redhaven', although there was a tendency for the sod treatments to reduce yield efficiency in some years in all the studies. Our previous work (Glenn and Welker, 1996) demonstrated that reducing the size of the vegetation-free area beneath peach trees from the time of planting resulted in stable yield efficiency over a seven year period, and the present study indicates that establishing a sod beneath mature peach trees tends to decrease yield efficiency. The difference apparently lies in how the tree alters dry matter partitioning in response to plant competition. Sod competition reduces root initiation (Glenn and Welker, 1989a, 1993; Parker et al. 1993). Starting peach trees in a small vegetation-free area immediately reduces tree growth (Welker and Glenn, 1985), whereas planting sod beneath trees with an established root system, as we did in this study, may require 4 or more years to reduce vegetative growth of the tree in the form of pruning weight without a reduction in trunk growth. It is apparently 


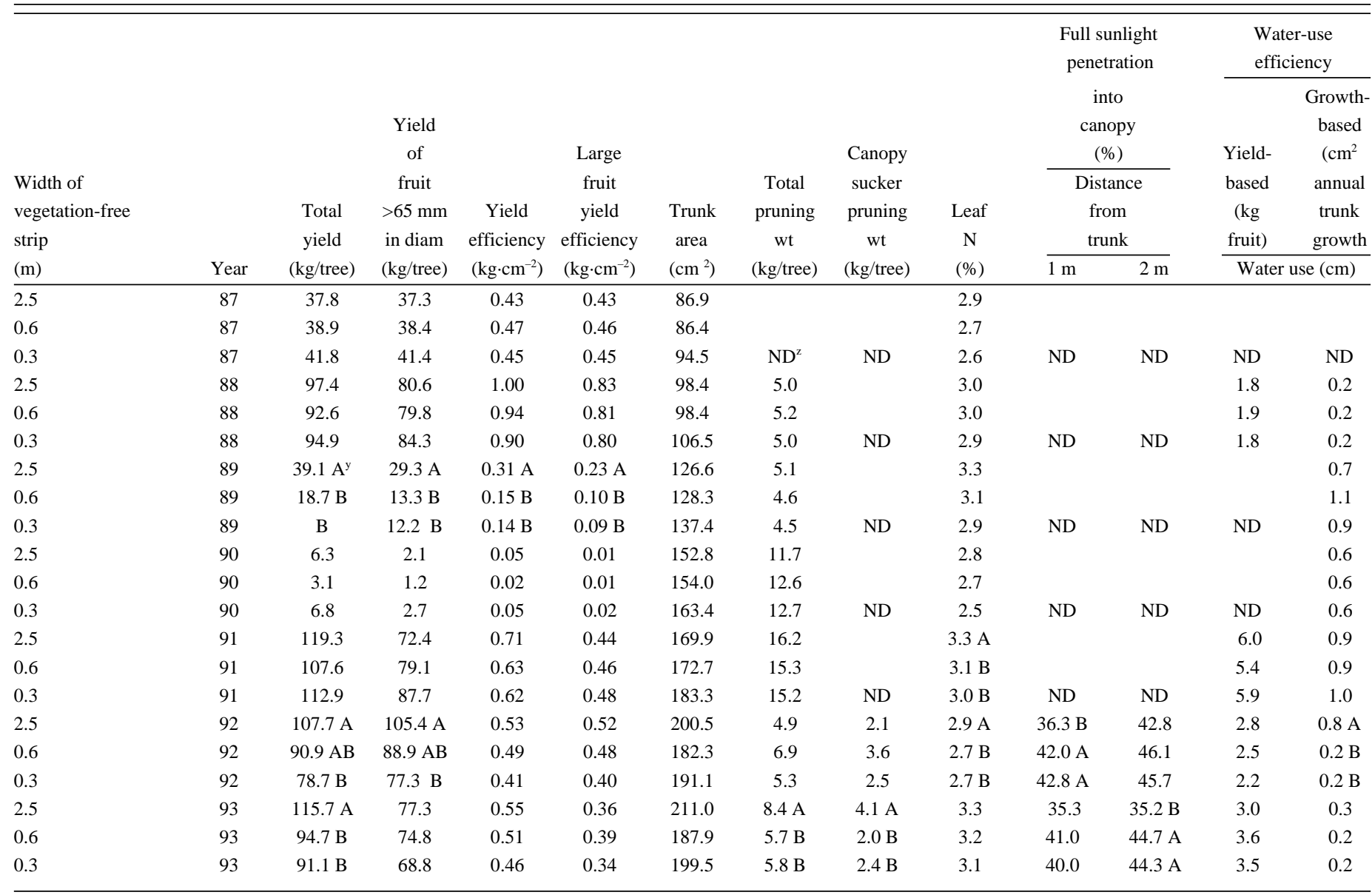

zNo data.

${ }^{\mathrm{y}}$ Mean separation within columns and years at $P<0.05$ by Ryan-Einot-Gabriel-Welsch test. Nonsignificant comparisons have no letter.

important to establish and maintain a small root system from the time of planting in order to maintain or increase yield efficiency (Boland et al. 1994; Glenn and Welker, 1996; Mandre et al. 1995; Myers, 1992; Ran et al. 1992; Williamson and Coston, 1990). Trying to reduce or restrict the size or efficiency of an established peach root system by imposing sod competition was not effective in our study.

There was severe frost damage to the flowers at bloom in 1990, reducing yield for all cultivars and treatments. No effect of sod treatments was visually noted or measured in yield or fruit size (Tables 1-3).

Trunk cross-sectional area was not reduced by the sod treatments in any of the studies indicating that the sod competition did not interfere with this component of growth. Total pruning weights were reduced for all years in the 'Harmony' and in none of the years for the 'Redhaven' study, yet in both studies, canopy suckers were reduced by planting sod beneath the trees indicating that different components of vegetative growth are affected by sod competition. Prior to measuring canopy sucker weight in 1992, we observed that the sod treatments were reducing vegetative growth, however, total pruning weight measurements did not consistently confirm our observations. Canopy sucker weights were more consistent than total pruning weight in demonstrating a reduction in vegetative growth due to sod competition. Light penetration consistently indicated a reduction in vegetative growth due to sod competition, since increased light penetration was measured in 1992 for the 'Summerglo' study when no difference was measured in total or canopy sucker pruning weights. The goal of vegetation control in tree fruit crops is to increase light penetration and fruit bearing wood, not reduce growth per se. Reducing canopy sucker growth is effective, since this growth directly interferes with light penetration into the canopy that is needed to initiate fruit buds (Faust, 1989).

Increasing the amount of ground cover is important in reducing rainfall runoff (Glenn and Welker, 1989b) and increasing soil organic matter (Welker and Glenn, 1988), which are key elements in a sustainable production system. Establishing sod beneath 3year-old peach trees increased soil water content in all years of the studies due in part to increased rainfall infiltration and reduced runoff. A rainfall event of $41 \mathrm{~mm}$ on $18 \mathrm{Aug}$. 1993, demonstrated the effect of the sod treatments (Figs. 1 and 2). Soil moisture increased for all treatments at the 0 to 30 depths on this date, however, the infiltration of the rainfall to the 30 to 60 and 60 to 90 $\mathrm{cm}$ depths is seen only in the sod treatments of the two studies. These results confirm earlier work of Kenworthy (1952) and Toenjes et al (1956) who demonstrated that a mature sod has higher available soil water than cultivated soils due in large part to increased rainfall infiltration.

Canopy leaf minus air temperatures in 1988 in the 'Redhaven' and 'Summerglo' studies demonstrated a consistent increase in peach tree canopy temperature in the sod treatments that is indicative of reduced transpiration (Glenn et al. 1989) despite greater soil water content. The intrusion of sod into the established root system of peach probably reduced peach root density (Glenn and Welker, 


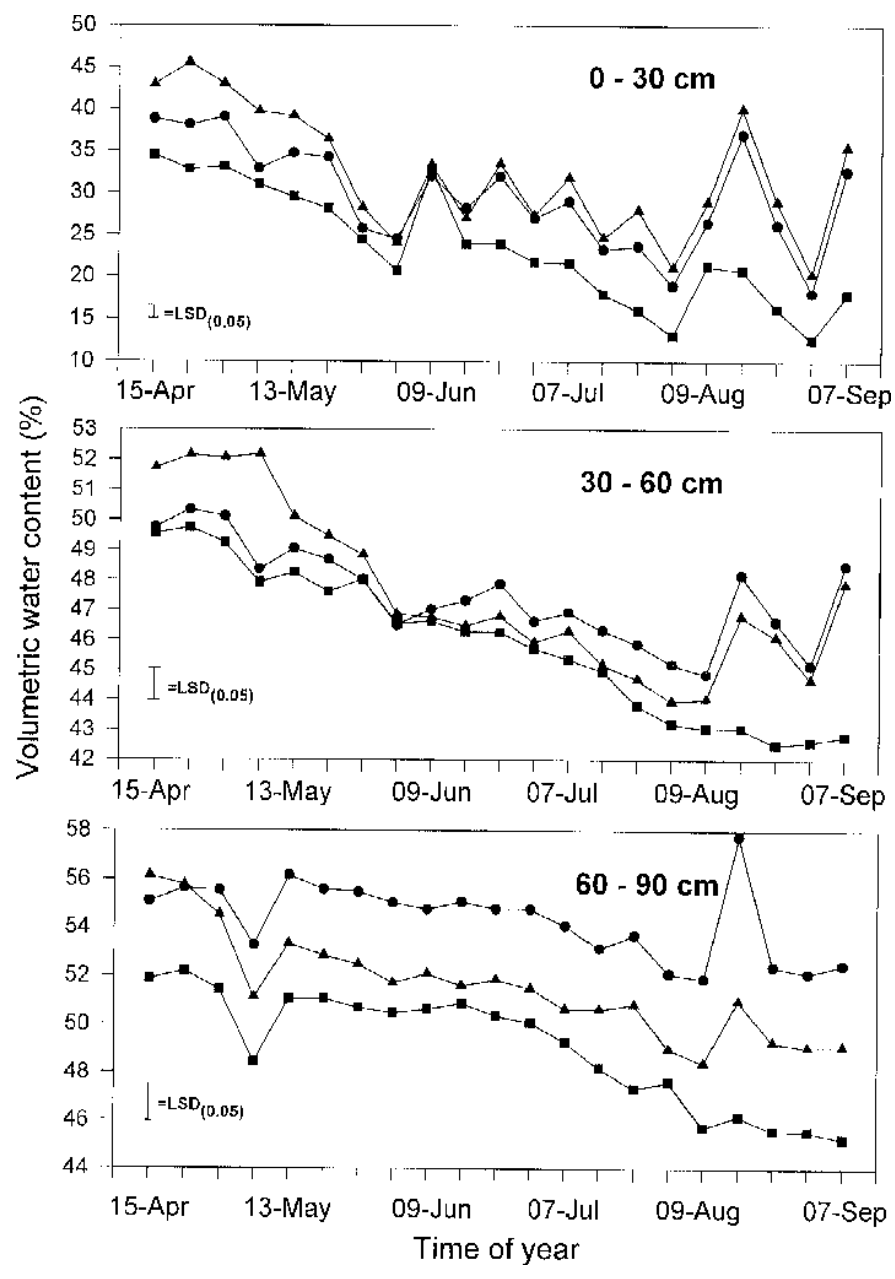

Fig. 2. The effect of grass species on the soil water content of the 'Redhaven' study in 1993. 2.5-m-wide herbicide strip, 'Reliant' fescue, $\boldsymbol{\Delta}$ Poa trivialis.

1989a), resulting in reduced water use and lower transpirational cooling of the canopy. Glenn and Welker (1991) have shown that peach water use is related to root length density and soil cover characteristics. The yield-based water use efficiency of 'Redhaven' and 'Summerglo' trees in the sod treatments was the same or greater than the 2.5 -m vegetation-free strip treatment ,supporting the value of increasing the amount of soil cover in orchard systems as part of a sustainable production system.

Cultural techniques to control tree size have included root pruning (Geisler and Ferree, 1984; Glenn and Miller, 1995), trunk scoring (Andrews et al. 1978; Fernandez-Escobar et al. 1987), root restriction with fabric and herbicides (Myers, 1992; Williamson and Coston, 1990), irrigation management (Chalmers et al. 1981; Mitchell et al. 1982, 1991; Proebsting et al. 1989), and sod management (Welker and Glenn, 1989; Glenn and Welker, 1996), and when the trees are continually grown with a restricted root system, yield efficiency is stable or increased. In the present study we found that planting sod beneath mature peach trees specifically to reduce vegetative growth resulted in reduced yield after several years, and inconsistent reduction in pruning weight, with no increase in yield efficiency. A proactive approach to preventing excessive vegetative growth by controlling root volume from the time of planting appears more effective than reactive measures to reduce excessive vegetative growth of mature peach trees through cultural practices that diminish the extent or effectiveness of the established root system.

\section{Literature Cited}

Andrews, C.P., W.B. Sherman, and R.H. Sharpe. 1978. Response of peach and nectarine cultivars to girdling. Proc. Fla. State Hort. Soc. 91:175-177.

Boland, A.M., P.D. Mitchell, I. Goodwin, and P.H. Jerie. 1994. The effect of soil volume on young peach tree growth and water use. J. Amer. Soc. Hort. Sci. 119:1157-1162.

Chalmers, D.J., P.D. Mitchell, and L. van Heek. 1981. Control of peach tree growth and productivity by regulated water supply, tree density, and summer pruning. J. Amer. Soc. Hort. Sci. 106:307-312.

Faust, M. 1989. Physiology of temperate zone fruit trees. Wiley, New York.

Fernandez-Escobar, R., R. Martin, P. Lopez-Riveras, and M. Pazsaurey. 1987. Girdling as a means of increasing fruit size and earliness in peach and nectarine cultivars. J. Hort. Sci. 62:493-498.

Geisler, D. and D.C. Ferree. 1984. Response of plants to root pruning. Hort. Rev. 6:155-188.

Glenn, D.M. and W.V. Welker. 1989a. Peach root development and tree hydraulic resistance under tall fescue sod. HortScience 24:117-119.

Glenn, D.M. and W.V. Welker. 1989b. Orchard soil management systems influence rainfall infiltration. J. Amer. Soc. Hort. Sci. 114:10-14.

Glenn, D.M., J.W. Worthington, W.V. Welker, and M.J. McFarland. 1989.

Estimation of peach tree water use using infrared thermometry. J. Amer. Soc. Hort. Sci. 114:737-741.

Glenn, D.M. and W.V. Welker. 1991. Soil management affects shoot and root growth, nutrient availability, and water uptake of young peach trees. J. Amer. Soc. Hort. Sci. 116:238-241.

Glenn, D.M. and W.V. Welker. 1993. Water transfer diminishes root competition between peach and tall fescue. J. Amer. Soc. Hort. Sci. 118:570-574.

Glenn, D.M. and S.S. Miller. 1995. Growth, yield, and water use responses of peach to repeated root pruning in a sub-humid climate. HortScience 30:543-546.

Glenn, D.M. and W.V. Welker. 1996. Sod competition in peach production: I. Managing sod proximity. J. Amer. Soc. Hort. Sci. 121:666-669.

Gradziel, T.M. and W. Beres. 1993. Semi-dwarf growth habit in Clingstone peach with desirable tree and fruit qualities. HortScience 78:1045-1047.

Guilivo, C., A. Pomina, and G. Costa. 1984. Effects of planting density on peach and nectarine productivity. J. Amer. Soc. Hort. Sci. 109:287-290.

Huslig, S.M., M.W. Smith, and G.H. Busewitz. 1993. Irrigation schedules and annual ryegrass as a ground cover to conserve water and control peach tree growth. HortScience 28:908-913.

Kenworthy, A.L. 1952. Moisture in orchard soils as influenced by age of sod and clean cultivation. Mich. Quart. Bul. 35(4):454-459.

Layne, R.E.C. 1987. Peach rootstocks, p. 185-216. In: R.C. Rom and R.F. Carlson (eds.). Rootstocks for fruit crops. Wiley, New York.

Lockard, R.G. and G.W. Schneider. 1981. Stock and scion growth relationships and the dwarfing mechanism in apple. Hort. Rev. (3):315-375.

Mandre, O., M. Reiger, S.C. Meyers, R. Severson, and J. Regnard. 1995. Interaction of root confinement and fruiting in peach. J. Amer. Soc. Hort. Sci. 120:228-234.

Miller, S.S. 1988. Plant bioregulators in apple and pear culture. Hort. Rev. 10:309-401.

Mitchell, P.D., A.M. Boland, J.L. Irvine, and P.H. Jerie. 1991. Growth and water use of young, closely planted peach trees. Scienta Hort. 47:283-293.

Mitchell, P.D. and D.J. Chalmers. 1982. The effect of reduced water supply on peach tree growth and yield. J. Amer. Soc. Hort. Sci. 107:853-856.

Myers, S.C. 1992. Root restriction of apple and peach with in-ground fabric containers. Acta Hort. 322:215-219.

Parker, M.L., J. Hull, and R.L. Perry. 1993. Orchard floor management affects peach rooting. J. Amer. Soc. Hort. Sci. 118:714-718.

Proebsting, E.L., P.H. Jerie, and J.L. Irvine. 1989. Water deficits and rooting volume modify peach tree growth and water relations. J. Amer. Soc. Hort. Sci. 114:368-372.

Ran, Y., B. Bar-Yosef, and A. Erez. 1992. Root volume influence on dry matter production and partitioning as related to nitrogen and water uptake rates by peach. J. Plant Nutr. 15:713-726.

Richards, D. and R.N. Rowe. 1977. Effects of root restriction, root pruning, and 6benzlaminopurine on the growth of peach seedlings. Ann. Bot. 41:729-740.

Toenjes, W., R.J. Higdon and A.L. Kenworthy. 1956. Soil moisture used by orchard sods. Mich. Quart. Bul. 39(2):334-352.

Welker, W.V. and D.M. Glenn. 1985. The relationship of sod proximity to the growth and nutrient composition of newly planted peach trees. HortScience 20:417-418.

Welker, W.V. and D.M. Glenn. 1988. Growth responses of young peach trees and changes in soil characteristics with sod and conventional planting systems. J. Amer. Soc. Hort. Sci. 113:652-656.

Welker, W.V. and D.M. Glenn. 1989. Sod proximity influences the growth and yield of young peach trees. J. Amer. Soc. Hort. Sci. 114:856-859.

Williamson, J.G. and D.C. Coston. 1990. Planting method and irrigation rate influence vegetative and reproductive growth of peach planted at high density. J. Amer. Soc. Hort. Sci. 115:207-212. 